\title{
Partial replacement of commercial soybean meal with raw, full-fat soybean meal supplemented with varying levels of protease in diets of broiler chickens
}

\author{
M.M. Erdaw ${ }^{1,3 \#, ~ R . A . ~ P e r e z-M a l d o n a d o ~}{ }^{2}$, M. Bhuiyan ${ }^{1} \&$ P. A. lji $^{1 \#}$ \\ ${ }^{1}$ School of Environmental and Rural Sciences, University of New England, Australia; ${ }^{2}$ DSM Nutritional Products, Animal \\ Nutrition and Health, 30 Pasir Panjang Road \#13-31Mapletree Business City Singapore 117440Singapore; ${ }^{3}$ Ethiopian \\ Institute of Agricultural Research, Debre-Zeit Centre, Ethiopia.
}

(Received 4 November 2016; Accepted 12 December 2016; First published online 21 December 2016)

Copyright resides with the authors in terms of the Creative Commons Attribution 4.0 South African License.

See: http://creativecommons.org/licenses/by/4.0/za

Condition of use: The user may copy, distribute, transmit and adapt the work, but must recognize the authors and the South African Journal of Animal Science.

\begin{abstract}
A 3 * 3 factorial study was used to evaluate the feed intake (FI), body weight gain (BWG), and feed conversion ratio (FCR) of broilers fed on the test diets. The commercial soybean meal (SBM) was replaced by raw, full-fat soybean meal (RSBM) at 0,10 or $20 \%$, equivalent to 0,30 and $60 \mathrm{~g} / \mathrm{kg}$ of diet, respectively, and the microbial protease was also supplemented in diets at $0.1,0.2$ or $0.3 \mathrm{~g} / \mathrm{kg}$, equivalent to 7500 , 15000 and 22500 PROT $/ \mathrm{kg}$ of diet, respectively. Microbial phytase (1000 FYT/kg) was uniformly added to each diet, which was fed to six replicate groups, with nine birds per replicate. Samples of test-ingredients and test-diets, after mixing, were also subjected to chemical analysis, prior to being used, to assess the nutritional compositions, particularly anti-nutritional factors. As the result of this study, the analysed concentrations of trypsin inhibitors ( $\mathrm{TI}$ ) in the diets ranging between 1730.5 and $9913.2 \mathrm{TIU} / \mathrm{g}$. Increasing the levels of RSBM in the diets reduced the $\mathrm{FI}$, during 1 to $35 \mathrm{~d}$ of age. Except in the starter phase, increasing the level of RSBM had no significant effect on BWG. When protease was added to the diets, the BWG was significantly improved during the periods of $1-10 d, 1-24 d$ and $1-35 d$. Feed efficiency was decreased by increasing the level of RSBM (1-10 d). Neither increasing levels of RSBM nor protease affected the yield of any meat part at $d 35$. The relative weight of the small intestine at $d 10$ increased with rising levels of RSBM, but was reduced when protease was added to the diets. In conclusion, commercial SBM could be replaced by RSBM up to $20 \%$ in diets for broilers when the test microbial protease is supplemented.
\end{abstract}

Keywords: Anti-nutritional factors, broiler chickens, carcass, growth performance, microbial protease, rawfull-fat soybean meal, trypsin inhibitors.

\#Corresponding authors: pij@@une.edu.au or leulmammo@yahoo.com

\section{Introduction}

Soybean meal (SBM) is an excellent source of protein in diets for poultry (Pettersson \& Pontoppidan, 2013). However, in addition to the fluctuation in supply and seasonal scarcity in some parts of the world, the price of SBM has been increasing over the years (Shi et al., 2012; Pettersson \& Pontoppidan, 2013). It is therefore more effective to use full-fat SBM to replace both commercial SBM and the oil in the diets for broilers (Popescu \& Criste, 2003). Full-fat soybean meal can be obtained either after heat treatment or from the raw full-fat soybean, which is known to be raw full-fat soybean meal (RSBM) (Erdaw et al., 2015a; Erdaw et al., 2015b).

The problem with RSBM, however, is the concentration of anti-nutritional factors (ANF) (Chen et al., 2013; Erdaw et al., 2016b). There are three well-known ANF in soybean - trypsin (protease) inhibitors (TI), lectins, and phytate (Chen et al., 2013; Pettersson \& Pontoppidan, 2013), among which the most important in raw soybean meals are the TI (Newkirk, 2010; Dourado et al., 2011). Friedman \& Brandon (2001) reported that protease inhibitors constitute approximately $6 \%$ of soya protein, while Pettersson \& Pontoppidan (2013) stated that the amount of ANF altogether constituted approximately $5 \%$ of the CP fraction of SBM, and large amounts of ANF are concentrated in the seed hull.

The nutritive value of raw full-fat soybean is negatively affected by the presence of ANF (Liu et al., 1997; Erdaw et al., 2016a), especially by trypsin inhibitors and lectins (Newkirk, 2010). Protein digestibility could be reduced by a multi-faceted action of ANF, including nutrient binding and increase in gut viscosity (Ao, 2011). Various scholars (Liu et al., 1997; Newkirk, 2010; Erdaw et al., 2015a; Erdaw et al., 2015b) have reported that feeding raw SBM with high levels of trypsin inhibitors and lectins negatively affects pancreatic function, the growth of birds, and feed efficiency. Mogridge et al. (1996) reported that the consumption of raw 
beans increased the size of the pancreas ( 0.80 vs $0.37 \%$ of live weight) and the duodenum ( 1.35 vs $1.0 \%$ of live weight) and reduced feed consumption and growth of the chicks (66 vs $97 \mathrm{~g} / 14 \mathrm{~d}$ ). Similarly, ASA (2004) reported that diets based on raw beans reduced feed consumption and live weight, and decreased the feed conversion indices by 14,35 , and $53 \%$, respectively.

Although treating the soybean seed by heat is the most common strategy to reduce the risks of ANF (Mayorga et al., 2011), heating may negatively influence the quality of the product (Căpriţă et al., 2010). Therefore, research (Costa et al., 2008; Dosković et al., 2013) has suggested that supplementation of poultry diets with exogenous enzymes may be effective. Microbial proteases are protein-digesting enzymes that are used in pig and poultry nutrition to break down the stored proteins and proteinaceous anti-nutrients in various plant materials (Ao, 2011; Barletta, 2011).

Supplementation of diets with microbial phytase increases the digestibility of CP and amino acids in plant-based proteins (Barletta, 2011; Guggenbuhl et al., 2012). The objectives of this study were to determine the composition of ANF, for example, trypsin inhibitors (TI), urease activities (UA) and nitrogen solubility index (NSI), in the test-ingredients and test-diets, and to evaluate the effects of microbial protease supplementation in diets containing varying levels of RSBM, with the possibility of improving the performance of broiler chickens.

\section{Materials and Methods}

The experiment was approved by the Animal Ethics Committee (Authority No: AEC14-005) of the University of New England (UNE), Australia, prior to commencement. The test raw soybean seed was purchased at harvest from a local producer in northern New South Wales, Australia. The raw full-fat seeds were cleaned and hammer-milled to pass through $2 \mathrm{~mm}$ sieve size and then used directly to partially replace commercial SBM. Commercial soybean meal (SBM) was obtained from Cargill (Australia) Pty Ltd in New South Wales. The crude protein content of the RSBM was about $38 \%$ (see Table 2), which looks lower than the value of its counterpart-SBM. The lower CP content for RSBM, when compared to its counterpart-SBM, might be due to the presence of the oil in it.

The experiment was a $3{ }^{*} 3$ factorial study, with 3 levels of RSBM (commercial SBM was replaced by RSBM at 0,10 , or $20 \%$, equivalent to 0,30 , and $60 \mathrm{~g} / \mathrm{kg}$ of the diet) and 3 levels of protease $(0.1,0.2$, or 0.3 $\mathrm{g} / \mathrm{kg}$, equivalent to 7500,15000 and 22500 PROT $/ \mathrm{kg}$ of diet, respectively) from Nocardiopsis prasine (Ronozyme® ProAct, DSM Nutritional Products, Australia Pty Ltd). Microbial phytase (1000 FYT/kg, DSM Nutrition Products) was uniformly supplemented across all the diets (Table 1). This experiment had no protease-free dietary treatment. The enzymes were added prior to pelleting at $65{ }^{\circ} \mathrm{C}$. Sub-samples of the test-diets, containing RSBM and enzymes, were then collected and analysed for TI (AOAC, 2006a), protein solubility (KOH) (Araba \& Dale, 1990), urease activity (UA) (AOCS, 2006a), and nitrogen solubility index (NSI) (AOCS, 2006b), and are summarised in Table $2 \& 3$.

The potential efficacy of Ronozyme® ProAct has been demonstrated at dose level of $15000 \mathrm{PROT} / \mathrm{kg}$ feed in chickens for fattening (EFSA, 2009). The activity of 6-phytase is expressed in phytase units (FYT, equivalent to FTU). According to the Applicant, one FYT unit is defined as the amount of enzyme that releases $1 \mu \mathrm{mol}$ of inorganic phosphate from phytate per minute under reaction conditions with a phytate concentration of $5.0 \mathrm{mM}$ at pH 5.5 and $37^{\circ} \mathrm{C}$ (EFSA, 2016).

A total of 486 day-old Ross 308 male broiler chicks (average initial weight, $40.24 \pm 0.097 \mathrm{~g}$ ), were obtained from a local commercial hatchery (Baiada Poultry Pty. Ltd., Tamworth, Australia). Nine chicks, of uniform body weight, were allocated to each cage $(600 \times 420 \times 23 \mathrm{~cm})$, and each diet was fed to 6 replicate cages from 0 to 35 days of age in climate-controlled rooms. The main reason why the trail was ended at $d$ 35 , instead of allowing for a longer period, was to enable achieving the locally required marketable live weight of birds. The feeders were scrubbed and cleaned before diets were provided. The drinkers were also checked from time to time to ensure water supply and cleanliness. The excreta trays were scrubbed and cleaned whenever they were full. The temperature of the rooms was set at $33^{\circ} \mathrm{C}$ for the first two days. This temperature was then gradually reduced to $24{ }^{\circ} \mathrm{C}$ at 19 days age and this was maintained for the remaining study period. For the first two days, $24 \mathrm{~h}$ light was provided. This was reduced to $23 \mathrm{~h}$ for the next six consecutive days, followed by $20 \mathrm{~h}$ light for the remaining days. Feed was provided ad libitum (crumbled for starters and pelleted for both grower and finisher), and the birds had free access to water. 
Table 1 Ingredient and composition of basal starter (0 - 10d), grower (10 - 24d) and finisher (24 - 35d) diets

\begin{tabular}{|c|c|c|c|c|c|c|c|c|c|}
\hline \multirow{3}{*}{ RSBM (g/kg of diet) } & \multicolumn{9}{|c|}{ Basal diets } \\
\hline & \multicolumn{3}{|c|}{ Starter $(0-10 d)$} & \multicolumn{3}{|c|}{ Grower (10 - $24 d)$} & \multicolumn{3}{|c|}{ Finisher (24 - $35 d)$} \\
\hline & 0 & 30 & 60 & 0 & 30 & 60 & 0 & 30 & 60 \\
\hline \multicolumn{10}{|l|}{ Ingredients (g/kg) } \\
\hline Corn (rolled) & 599.0 & 593.8 & 614.9 & 607.3 & 606.7 & 605.9 & 612.4 & 612.0 & 617.0 \\
\hline Soybean meal & 300.0 & 270.0 & 240.0 & 300.0 & 270.0 & 240.0 & 300.0 & 270.0 & 240.0 \\
\hline Raw soybean meal & 0.0 & 30.0 & 60.0 & 0.0 & 30.0 & 60.0 & 0.0 & 30.0 & 60.0 \\
\hline Meat meal & 53.0 & 62.8 & 43.7 & 25.0 & 30.0 & 35.0 & 15.0 & 15.0 & 15.0 \\
\hline Limestone & 10.4 & 10.0 & 10.0 & 8.9 & 8.3 & 7.9 & 9.3 & 10.0 & 9.4 \\
\hline Dical Phos & 6.5 & 6.0 & 7.1 & 7.5 & 6.9 & 6.3 & 7.9 & 9.4 & 8.7 \\
\hline Canola oil & 14.0 & 10.5 & 6.4 & 34.7 & 31.7 & 28.6 & 42.6 & 39.8 & 37.1 \\
\hline $\mathrm{TiO}_{2}$ & 5.0 & 5.0 & 5.0 & 5.0 & 5.0 & 5.0 & 5.0 & 5.0 & 5.0 \\
\hline L-Lysine & 3.0 & 3.0 & 3.5 & 2.4 & 2.3 & 2.2 & 0.5 & 0.5 & 0.5 \\
\hline DL-Methionine & 3.0 & 2.2 & 2.8 & 3.3 & 3.3 & 3.4 & 3.0 & 3.5 & 3.0 \\
\hline Salt & 2.1 & 2.0 & 2.0 & 2.5 & 2.5 & 2.5 & 2.0 & 2.0 & 2.0 \\
\hline L-Threonine & 1.0 & 1.9 & 1.7 & 0.8 & 0.8 & 0.8 & 0.2 & 0.5 & 0.2 \\
\hline Sodium bicarbonate & 1.2 & 1.0 & 1.1 & 0.76 & 0.70 & 0.60 & 0.2 & 0.2 & 0.2 \\
\hline Trace mineral, $0.75 \mathrm{~kg} / \mathrm{mt}^{1}$ & 0.75 & 0.75 & 0.75 & 0.75 & 0.75 & 0.75 & 0.75 & 0.75 & 0.75 \\
\hline Choline $\mathrm{Cl}$ & 0.5 & 0.5 & 0.5 & 0.5 & 0.5 & 0.5 & 0.5 & 0.75 & 0.5 \\
\hline Vitamins, $0.5 \mathrm{~kg} / \mathrm{mt}^{2}$ & 0.5 & 0.5 & 0.5 & 0.5 & 0.5 & 0.5 & 0.5 & 0.5 & 0.5 \\
\hline Phytase & 0.1 & 0.1 & 0.1 & 0.1 & 0.1 & 0.1 & 0.1 & 0.1 & 0.1 \\
\hline \multicolumn{10}{|l|}{ Nutrients (g/kg) } \\
\hline ME poultry (MJ/kg) & 12.59 & 12.59 & 12.59 & 13.18 & 13.18 & 13.18 & 13.39 & 13.39 & 13.39 \\
\hline Crude protein & 220.6 & 220.0 & 220.0 & 218.8 & 212.5 & 212.7 & 204.6 & 202.1 & 199.6 \\
\hline Crude fat & 37.4 & 37.2 & 37.2 & 55.1 & 56.6 & 58.1 & 61.9 & 63.3 & 64.6 \\
\hline Arginine & 14.4 & 13.8 & 13.8 & 13.4 & 13.4 & 13.5 & 13.0 & 12.9 & 12.8 \\
\hline Lysine & 14.0 & 13.9 & 13.9 & 12.7 & 12.7 & 12.7 & 10.9 & 10.8 & 10.7 \\
\hline Methionine & 6.2 & 5.8 & 5.8 & 6.3 & 6.3 & 6.3 & 5.9 & 5.8 & 5.8 \\
\hline Methionine + cystine & 9.4 & 8.9 & 8.9 & 9.4 & 9.4 & 9.4 & 8.9 & 8.8 & 8.7 \\
\hline Threonine & 8.9 & 9.4 & 9.4 & 8.3 & 8.3 & 8.3 & 7.5 & 7.5 & 7.4 \\
\hline Calcium & 10.7 & 10.7 & 10.7 & 9.0 & 9.0 & 9.0 & 8.5 & 8.5 & 8.5 \\
\hline Phosphorus (avail) & 5.4 & 5.0 & 5.0 & 4.5 & 4.5 & 4.5 & 4.2 & 4.2 & 4.2 \\
\hline Sodium & 1.9 & 1.6 & 1.6 & 1.6 & 1.6 & 1.6 & 1.2 & 1.2 & 1.2 \\
\hline Chloride & 2.6 & 2.6 & 2.6 & 2.6 & 2.6 & 2.6 & 1.9 & 1.9 & 1.9 \\
\hline Choline & 1.5 & 1.3 & 1.3 & 1.3 & 1.3 & 1.3 & 1.4 & 1.3 & 1.3 \\
\hline \multicolumn{10}{|c|}{ 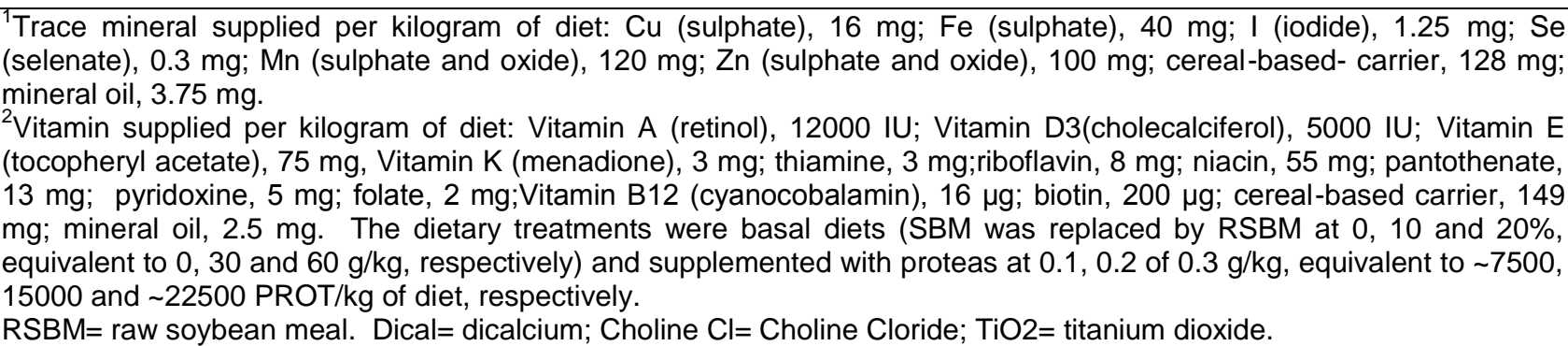 } \\
\hline
\end{tabular}


The birds were provided with starter $(0-10 d)$, grower (10 - $24 d)$ and finisher (24 - $35 d$ ) diets (corn-soybean based) formulated to Aviagen standards for Ross 308. Mortality of birds was recorded whenever it occurred. On each of the 10,24, and 35 days of age, one bird per replicate was randomly selected and killed using cervical dislocation. The weight of the internal organs, such as the gizzard, proventriculus, small intestine, pancreas, liver, spleen and bursa, was recorded on each of the 10,24, and 35 days of age; the average live weight of the birds was recorded per cage. The leftover feed was also weighed to calculate the FI of the birds for each phase, and the FCR was computed for each cage using the BWG and the FI. Meat yield was measured at 35 days of age. Two birds were randomly selected from each cage and humanely killed by cervical dislocation, scalded, and plucked. The head, legs, and all visceral organs of the birds were then removed, and the dressed carcass was weighed. The main carcass parts, including the breast, drumsticks, thighs, wings, and neck, were then cut out and weighed to evaluate their weights, relative to dressed carcass weight. Meat parts were used with their bones (i.e. no deboned meat part was used in the data). The total $\mathrm{N}$ content of ingredient samples (e.g. RSBM, and commercial SBM) and diets containing RSBM was determined by the Dumas' combustion technique (LECO); Official Method 990.03 (Kjeldahl), and 984.13 (AD), (AOAC, 2006b). The CP content of the sample was derived from the $\mathrm{N}$ content using a multiplication factor of 6.25. Available lysine was measured using Method 975.44 (AOAC, 2006c).

Descriptive statistics was used to analyse the data of nutritional composition of the test-ingredient and test-diets. One-way ANOVA and general linear model (GLM) of Minitab software version 17 (Minitab, 2013) were used to compare the mean values of treatments, and main factors (RSBM level and enzyme supplementation, as well as their interactions) of the feeding trail. The differences between the mean values were considered to be significant at $P<0.05$, and these mean values were also separated using Duncan's test.

\section{Results}

Nutrient composition and values of quality measuring paramters of RSBM in comparison to the commercial SBM are shown in Tables 2 and 3.

Table 2 Analysed values of nutrient composition and quality measuring parameters of raw soybean meal (RSBM) in comparison to the commercial soybean meal

\begin{tabular}{|c|c|c|c|c|c|c|c|c|c|c|c|}
\hline & \multicolumn{7}{|c|}{ Composition (g/kg) } & \multicolumn{4}{|c|}{ Quality measuring parameters } \\
\hline & DM & CF & $\mathrm{CP}$ & EE & $\begin{array}{c}\text { Total } \\
\text { Sugars }\end{array}$ & $\begin{array}{l}\text { Total } \\
\text { starch }\end{array}$ & $\begin{array}{l}\text { AME, } \\
\mathrm{MJ} / \mathrm{kg}\end{array}$ & $\begin{array}{l}\text { Avail. } \\
\text { lysine }\end{array}$ & $\begin{array}{c}\mathrm{KOH}, \\
\mathrm{g} / \mathrm{kg}\end{array}$ & $\begin{array}{c}\text { TI, } \\
\text { TIU/g }\end{array}$ & $\begin{array}{l}\mathrm{UA}, \\
\Delta \mathrm{pH}\end{array}$ \\
\hline RSBM & 923.6 & 62.0 & 382.4 & 147.3 & 95.0 & 26.1 & 12.6 & 26.4 & 898.6 & 13498 & 2.1 \\
\hline \multirow[t]{3}{*}{ SBM } & 914.8 & 37.9 & 422.9 & 19.2 & 107.6 & 37.0 & 9.0 & 28.4 & 794.4 & 5743 & 0.09 \\
\hline & \multicolumn{11}{|c|}{ Amino acid composition $(\mathrm{mg} / \mathrm{g})$} \\
\hline & Met & Lys & Iso & Leu & Cys & Thr & His & Arg & Val & Ala & Try \\
\hline RSBM & 5.6 & 26.6 & 17.9 & 31.0 & 6.0 & 16.1 & 10.9 & 32.9 & 18.7 & 17.3 & 4.7 \\
\hline SBM & 6.2 & 29.0 & 20.5 & 35.6 & 6.0 & 18.2 & 12.1 & 32.9 & 21.9 & 20.3 & 6.5 \\
\hline
\end{tabular}

As shown in Table 3 the values of TI, NSI and UA were increased from 1747 to $9913.2 \mathrm{TIU} / \mathrm{g}, 155.3$ to $206.1 \mathrm{~g} / \mathrm{kg}$ and 0.16 to $1.40 \Delta \mathrm{pH}$, respectively as the level of RSBM increased in the diet.

The results of the gross response of the birds, in terms of FI, BWG and FCR, are shown in Table 4. During the period from 1 to $35 \mathrm{~d}$, feed consumption was reduced $(P<0.01)$ in line with increasing the level of RSBM in the diets, but this had no similar influence $(P>0.05)$ in the early period $(1-10 \mathrm{~d}$ or $1-24 \mathrm{~d})$. Increasing the level of protease had no influence $(P>0.05)$ on the $\mathrm{FI}$ over the entire trial period. The BWG of the birds, during $1-10 \mathrm{~d}$ was negatively affected $(P<0.001)$ by rising an inclusion rate of RSBM in diets. The BWG (during 1 - 24 days) was reduced by up to $3.1 \%$ at the highest level of RSBM in the diet, although this was not statistically significant $(P>0.05)$. 
Table 3 Effect of replacing commercial soybean meal by raw soybean meal in broiler diet $(\mathrm{g} / \mathrm{kg})$

\begin{tabular}{lccc}
\hline & \multicolumn{3}{c}{ RSBM in diet $(\mathrm{g} / \mathrm{kg})$} \\
\cline { 2 - 4 } & 0 & 30 & 60 \\
\hline Available lysine & 16.2 & 14.8 & 15.6 \\
Nitrogen solubility index $(\mathrm{NSI})$ & 155.3 & 169.0 & 206.1 \\
Protein solubility in $\mathrm{KOH}$ & 670.3 & 502.5 & 603.4 \\
Trypsin inhibitors $(\mathrm{TIU} / \mathrm{g})$ & 1747.3 & 5881.2 & 9913.2 \\
Urease activity $(\Delta \mathrm{pH})$ & 0.16 & 0.60 & 1.40 \\
\hline
\end{tabular}

Table 4 Response of broiler chickens, in terms of feed intake $(\mathrm{g} / \mathrm{b})$, body weight gain $(\mathrm{g} / \mathrm{b})$ and feed conversion ratio (FCR) of between hatch and 10, 24 or 35 days of age

\begin{tabular}{|c|c|c|c|c|c|c|c|c|c|c|}
\hline \multirow{2}{*}{$\begin{array}{l}\text { RSBM }{ }^{1} \\
\mathrm{~g} / \mathrm{kg}\end{array}$} & \multirow{2}{*}{$\begin{array}{l}\text { Protease } \\
\mathrm{g} / \mathrm{kg}\end{array}$} & \multicolumn{3}{|c|}{ Feed intake (days) } & \multicolumn{3}{|c|}{ Body weight gain (days) } & \multicolumn{3}{|c|}{ FCR (days) } \\
\hline & & $1-10$ & $1-24$ & $1-35$ & $1-10$ & $1-24$ & $1-35$ & $1-10$ & $1-24$ & $1-35$ \\
\hline \multirow{3}{*}{0} & 0.1 & 253.6 & 1894.7 & 3897.9 & 238.1 & 1411.2 & 2453.3 & 1.08 & 1.36 & 1.60 \\
\hline & 0.2 & 261.6 & 1753.8 & 3669.6 & 242.8 & 1414.3 & 2474.6 & 1.07 & 1.29 & 1.48 \\
\hline & 0.3 & 267.0 & 1817.8 & 3776.0 & 245.1 & 1442.0 & 2562.4 & 1.07 & 1.25 & 1.47 \\
\hline \multirow[b]{2}{*}{30} & 0.1 & 264.4 & 1839.1 & 3581.4 & 231.7 & 1383.1 & 2348.7 & 1.09 & 1.33 & 1.53 \\
\hline & 0.2 & 267.6 & 1747.2 & 3418.6 & 241.8 & 1349.4 & 2350.7 & 1.10 & 1.30 & 1.46 \\
\hline \multirow{4}{*}{60} & 0.3 & 263.3 & 1734.2 & 3502.4 & 242.8 & 1407.5 & 2475.2 & 1.07 & 1.24 & 1.42 \\
\hline & 0.1 & 259.9 & 1735.7 & 3458.2 & 219.7 & 1356.4 & 2348.4 & 1.16 & 1.32 & 1.48 \\
\hline & 0.2 & 245.7 & 1820.6 & 3586.0 & 220.1 & 1361.3 & 2437.1 & 1.14 & 1.31 & 1.47 \\
\hline & 0.3 & 271.1 & 1786.1 & 3529.4 & 235.9 & 1418.7 & 2484.6 & 1.14 & 1.26 & 1.45 \\
\hline \multicolumn{2}{|c|}{ Pooled SEM } & 2.01 & 15.42 & 34.73 & 1.62 & 8.63 & 21.43 & 0.012 & 0.011 & 0.022 \\
\hline \multicolumn{11}{|c|}{ Main effects } \\
\hline \multicolumn{2}{|l|}{0} & 260.7 & 1822.1 & $3780.9^{\mathrm{a}}$ & $242.0^{\mathrm{a}}$ & 1422.5 & 2499.3 & $1.07^{\mathrm{b}}$ & 1.30 & 1.52 \\
\hline \multicolumn{2}{|l|}{30} & 265.1 & 1773.5 & $3500.8^{b}$ & $238.8^{a}$ & 1379.9 & 2391.6 & $1.08^{\mathrm{b}}$ & 1.29 & 1.47 \\
\hline \multirow[t]{4}{*}{60} & & 258.9 & 1780.8 & $3524.5^{\mathrm{b}}$ & $225.2^{\mathrm{b}}$ & 1378.8 & 2424.2 & $1.15 \mathrm{a}$ & 1.29 & 1.47 \\
\hline & 0.1 & 259.3 & 1823.2 & 3631.0 & $229.8^{\mathrm{b}}$ & $1383.6^{\mathrm{ab}}$ & 2381.3 & 1.11 & $1.34^{\mathrm{b}}$ & 1.54 \\
\hline & 0.2 & 258.3 & 1773.9 & 3551.5 & $234.9^{\mathrm{ab}}$ & $1375.0^{\mathrm{b}}$ & 2420.8 & 1.11 & $1.30^{\mathrm{ab}}$ & 1.47 \\
\hline & 0.3 & 267.1 & 1779.3 & 3602.6 & $241.3^{\mathrm{a}}$ & $1422.7^{\mathrm{a}}$ & 2508.7 & 1.09 & $1.25^{\mathrm{a}}$ & 1.45 \\
\hline \multicolumn{11}{|c|}{ Sources of variation } \\
\hline \multicolumn{2}{|c|}{ RSBM } & NS & NS & ** & $\star \star * *$ & NS & NS & *** & NS & NS \\
\hline \multicolumn{2}{|c|}{ Protease } & NS & NS & NS & ** & * & 0.06 & NS & ** & NS \\
\hline \multicolumn{2}{|c|}{ RSBM $\times$ protease } & NS & NS & NS & NS & NS & NS & NS & NS & NS \\
\hline
\end{tabular}


Supplementation of the diet with increasing levels of protease improved the BWG during $1-10 \mathrm{~d}(P$ $<0.01)$ and $1-24 \mathrm{~d}(P<0.05)$. Body weight gain also tended $(P=0.06)$ to improve over the period from 1 to $35 \mathrm{~d}$ in response to protease supplementation. The birds fed on diets containing the highest level of the RSBM grew poorly $(P<0.01)$ during the early assessed period $(1-10 \mathrm{~d})$. Feed efficiency was also reduced by between 0.8 and $3.3 \%$, but this was not significantly affected $(P>0.05)$ during $1-24 \mathrm{~d}$ or $1-35 \mathrm{~d}$.

Table 5 The relative weights of meat parts (weight of meat part $(\mathrm{g}) /$ weight of a carcass $(\mathrm{kg})$ ) of broiler fed different diets at $35 \mathrm{~d}$ of age

\begin{tabular}{|c|c|c|c|c|c|c|c|}
\hline \multirow{2}{*}{ RSBM1 (g/kg) } & \multirow{2}{*}{ Protease $(\mathrm{g} / \mathrm{kg})$} & \multirow{2}{*}{ Dressed (\%) } & \multicolumn{5}{|c|}{ Relative Weights } \\
\hline & & & Breast & Thigh & Drumstick & Wing & Neck \\
\hline & 0.1 & 75.8 & 347 & 139 & 129 & 94 & 54 \\
\hline & 0.2 & 77.6 & 349 & 138 & 127 & 97 & 57 \\
\hline & 0.3 & 75.5 & 344 & 138 & 126 & 96 & 51 \\
\hline & 0.1 & 75.6 & 341 & 135 & 130 & 104 & 54 \\
\hline \multirow[t]{3}{*}{30} & 0.2 & 75.0 & 344 & 138 & 122 & 102 & 48 \\
\hline & 0.3 & 75.8 & 343 & 136 & 124 & 95 & 53 \\
\hline & 0.1 & 76.4 & 343 & 137 & 127 & 97 & 59 \\
\hline \multirow[t]{2}{*}{60} & 0.2 & 75.1 & 336 & 139 & 127 & 95 & 54 \\
\hline & 0.3 & 75.1 & 344 & 138 & 125 & 99 & 52 \\
\hline Pooled SEM & & 0.33 & 2.10 & 1.21 & 1.22 & 1.23 & 1.33 \\
\hline \multicolumn{8}{|l|}{ Main effects } \\
\hline 0 & & 76.3 & 347 & 138 & 127 & 96 & 54 \\
\hline 30 & & 75.5 & 343 & 136 & 126 & 100 & 52 \\
\hline \multirow[t]{4}{*}{60} & & 75.6 & 341 & 138 & 126 & 97 & 55 \\
\hline & 0.1 & 75.9 & 344 & 137 & 129 & 98 & 56 \\
\hline & 0.2 & 75.9 & 343 & 138 & 125 & 98 & 53 \\
\hline & 0.3 & 75.5 & 344 & 137 & 125 & 97 & 52 \\
\hline \multicolumn{8}{|l|}{ Sources of variation } \\
\hline RSBM & & NS & NS & NS & NS & NS & NS \\
\hline Protease & & NS & NS & NS & NS & NS & NS \\
\hline RSBM $x$ protease & & NS & NS & NS & NS & NS & NS \\
\hline
\end{tabular}

Feed efficiency was improved $(P<0.01)$ during the $1-24 \mathrm{~d}$ period in response to increasing the level of protease supplementation. During any of the assessed periods (1-10 d, $1-24 \mathrm{~d}$ or $1-35 \mathrm{~d})$, no significant interaction effect was observed on the FI, BWG or FCR between protease and RSBM. There was also no significant $(P>0.05)$ difference in the mortality of the birds between treatment groups during the entire study period. Only 23 birds died out of 486 , and this was not treatment-specific.

Results of carcass yield and the meat parts of birds at 35 days of age are shown in Table 5 . Increasing the level of RSBM in diets decreased (not significantly) the breast meat and drumstick weight by 1.7 and $0.8 \%$, respectively. Increasing the protease level $(0.1$ to $0.3 \mathrm{~g} / \mathrm{kg})$ in the diets reduced the relative weight of drumsticks by $1.0 \%$ at $35 \mathrm{~d}$ of age. No meat part was affected by interaction between the main factors (RSBM $x$ protease).

As shown in Table 6 , the weight of bursa was influenced $(P=0.05)$ by interaction between the main factors (RSBM x protease) in diets, but this interaction had no significant $(P>0.05)$ influence on the weight of any other internal organs at $10 \mathrm{~d}$ of age. Birds fed diets containing no RSBM (\% of RSBM $/ \mathrm{kg}$ of diets) had the lowest weight of bursa at $10 \mathrm{~d}$ of age. Except for the small intestine $(P<0.05)$ and pancreas, increasing the level of RSBM in the diets had no influence $(P>0.05)$ on the weight of other internal organs, including the gizzard and proventriculus $(\mathrm{G}+\mathrm{P})$, liver, heart, bursa, and spleen at $10 \mathrm{~d}$ of age. The weight of the small intestine was also reduced $(P<0.01)$ in response to increasing the inclusion rate of microbial protease in 
diets, particularly at $0.3 \mathrm{~g} / \mathrm{kg}$. Increasing the level of protease in diets, had no $(P>0.05)$ influence on the weight of any other internal organs.

Table 6 Weights of visceral organs ( $\mathrm{g} / 100 \mathrm{~g}$ of body weight) of broiler chickens on different diets at 10 days of age

\begin{tabular}{|c|c|c|c|c|c|c|c|c|}
\hline $\begin{array}{l}\mathrm{RSBM}^{1} \\
\mathrm{~g} / \mathrm{kg}\end{array}$ & $\begin{array}{c}\text { Protease } \\
\mathrm{g} / \mathrm{kg}\end{array}$ & $\begin{array}{c}\text { S. } \\
\text { intestine }\end{array}$ & Pancreas & Liver & $\mathrm{G}+\mathrm{P}$ & Heart & Bursa & Spleen \\
\hline \multirow[t]{3}{*}{0} & 0.1 & 8.5 & 0.510 & 4.3 & 4.0 & 0.98 & 0.15 & 0.09 \\
\hline & 0.2 & 8.0 & 0.513 & 4.0 & 3.7 & 0.89 & 0.15 & 0.08 \\
\hline & 0.3 & 7.0 & 0.607 & 4.3 & 3.7 & 0.90 & 0.16 & 0.08 \\
\hline \multirow[t]{3}{*}{30} & 0.1 & 8.7 & 0.645 & 4.3 & 3.8 & 0.10 & 0.20 & 0.09 \\
\hline & 0.2 & 7.9 & 0.590 & 4.0 & 3.7 & 0.94 & 0.17 & 0.06 \\
\hline & 0.3 & 8.1 & 0.605 & 3.9 & 3.9 & 0.99 & 0.17 & 0.08 \\
\hline \multirow[t]{3}{*}{60} & 0.1 & 8.7 & 0.692 & 4.3 & 4.0 & 0.82 & 0.17 & 0.09 \\
\hline & 0.2 & 8.7 & 0.733 & 3.8 & 3.7 & 0.89 & 0.17 & 0.08 \\
\hline & 0.3 & 8.3 & 0.705 & 4.0 & 3.7 & 0.90 & 0.19 & 0.08 \\
\hline \multicolumn{2}{|c|}{ Pooled SEM } & 0.02 & 0.02 & 0.26 & 0.28 & 0.02 & 0.01 & 0.00 \\
\hline \multicolumn{9}{|c|}{ Main effects } \\
\hline \multicolumn{2}{|l|}{0} & $7.8^{\mathrm{b}}$ & $0.543^{c}$ & 4.2 & 3.8 & 0.92 & 0.15 & 0.08 \\
\hline \multicolumn{2}{|l|}{30} & $8.2^{\mathrm{ab}}$ & $0.613^{b}$ & 4.1 & 3.8 & 0.96 & 0.18 & 0.08 \\
\hline \multirow[t]{4}{*}{60} & & $8.6^{\mathrm{a}}$ & $0.710^{\mathrm{a}}$ & 4.0 & 3.8 & 0.87 & 0.18 & 0.08 \\
\hline & 0.1 & $8.6^{\mathrm{a}}$ & 0.616 & 4.3 & 3.9 & 0.92 & 0.17 & 0.09 \\
\hline & 0.2 & $8.2^{\mathrm{ab}}$ & 0.612 & 3.9 & 3.7 & 0.91 & 0.16 & 0.07 \\
\hline & 0.3 & $7.9^{\mathrm{b}}$ & 0.639 & 4.0 & 3.8 & 0.93 & 0.17 & 0.08 \\
\hline \multicolumn{9}{|c|}{ Sources of variation } \\
\hline \multicolumn{2}{|l|}{ RSBM } & * & $* \star *$ & NS & NS & NS & NS & NS \\
\hline \multicolumn{2}{|c|}{ Protease } & ** & NS & NS & NS & NS & NS & NS \\
\hline \multicolumn{2}{|c|}{ RSBM $\times$ protease } & NS & NS & NS & NS & NS & $P=0.05$ & NS \\
\hline
\end{tabular}

${ }^{a, b, c}$ Means bearing uncommon superscripts within a column are significantly different at NS= non-significant; ${ }^{*} P<0.05$; ${ }^{* \star} P<0.01$; ${ }^{1} \mathrm{RSBM}=$ raw soybean meal; $\mathrm{SEM}=$ pooled standard error of means; $\mathrm{S}$. intestine= small intestine (duodenum + jejunum and ileum were weighed with their contents); gizzard and provetriculus were emptied (no content inside); G+P = gizzard + proventriculus. (SBM was replaced by RSBM at 0, 10 and 20\%, equivalent to 0, 30 and $60 \mathrm{~g} / \mathrm{kg}$, respectively, and supplemented with proteas at $0.1,0.2$ of $0.3 \mathrm{~g} / \mathrm{kg}$, equivalent to $\sim 7500,15000$ and $\sim 22500$ PROT/kg of diet, respectively.)

Increasing the inclusion rate of RSBM, as a main factor had no impact $(P>0.05)$ on the weight of any internal organ at $24 \mathrm{~d}$ of age. Supplementation of diets with microbial protease decreased $(P<0.01)$ the weight of the small intestine, but no other organ weight was affected $(P>0.05)$.

As shown in Table 7, neither inclusion of RSBM, protease supplementation, or their interaction had any effect $(P>0.05)$ on visceral organ weights at $24 \mathrm{~d}$, but the weight of the pancreas was reduced $(P$ $<0.001$ ) by increasing supplementation of RSBM at both 10 and $24 \mathrm{~d}$ of age. 
Table 7 The weights of visceral organ ( $\mathrm{g} / 100 \mathrm{~g}$ of body weight) of broiler chickens on different diets at $24 \mathrm{~d}$ of age

\begin{tabular}{|c|c|c|c|c|c|c|c|c|}
\hline $\begin{array}{l}\begin{array}{l}R_{S B M}{ }^{1} \\
(\mathrm{~g} / \mathrm{kg})\end{array} \\
\end{array}$ & $\begin{array}{c}\text { Protease } \\
(\mathrm{g} / \mathrm{kg})\end{array}$ & S. intestine & Pancreas & Liver & $G+P$ & Heart & Bursa & Spleen \\
\hline \multirow[t]{3}{*}{0} & 0.1 & 4.4 & 0.230 & 2.6 & 1.9 & 0.72 & 0.16 & 0.10 \\
\hline & 0.2 & 5.2 & 0.220 & 2.7 & 1.9 & 0.73 & 0.15 & 0.10 \\
\hline & 0.3 & 4.6 & 0.245 & 2.6 & 1.9 & 0.72 & 0.20 & 0.10 \\
\hline \multirow[t]{3}{*}{30} & 0.1 & 5.5 & 0.295 & 2.5 & 2.0 & 0.65 & 0.18 & 0.09 \\
\hline & 0.2 & 5.2 & 0.315 & 2.7 & 2.1 & 0.74 & 0.17 & 0.08 \\
\hline & 0.3 & 5.4 & 0.305 & 2.6 & 2.0 & 0.79 & 0.17 & 0.09 \\
\hline \multirow[t]{3}{*}{60} & 0.1 & 5.4 & 0.357 & 2.5 & 2.1 & 0.71 & 0.21 & 0.10 \\
\hline & 0.2 & 5.5 & 0.340 & 2.6 & 2.2 & 0.75 & 0.16 & 0.11 \\
\hline & 0.3 & 5.7 & 0.327 & 2.9 & 2.0 & 0.76 & 0.16 & 0.08 \\
\hline \multicolumn{2}{|c|}{ Pooled SEM } & 0.11 & 0.01 & 0.01 & 0.03 & 0.02 & 0.01 & 0.00 \\
\hline \multicolumn{9}{|c|}{ Main effects } \\
\hline \multicolumn{2}{|l|}{0} & 4.7 & $0.232^{c}$ & 2.6 & 1.9 & 0.73 & 0.17 & 0.10 \\
\hline \multicolumn{2}{|l|}{30} & 5.4 & $0.305^{\mathrm{b}}$ & 2.7 & 2.0 & 0.72 & 0.18 & 0.09 \\
\hline \multirow[t]{4}{*}{60} & & 5.5 & $0.341^{\mathrm{a}}$ & 2.6 & 2.1 & 0.75 & 0.18 & 0.10 \\
\hline & 0.1 & 5.1 & 0.294 & 2.6 & 2.0 & 0.70 & 0.18 & 0.10 \\
\hline & 0.2 & 5.3 & 0.292 & 2.6 & 2.1 & 0.74 & 0.16 & 0.10 \\
\hline & 0.3 & 5.2 & 0.292 & 2.7 & 1.9 & 0.75 & 0.18 & 0.09 \\
\hline \multicolumn{9}{|c|}{ Sources of variation } \\
\hline \multicolumn{2}{|c|}{ RSBM } & NS & $* * *$ & NS & NS & NS & NS & NS \\
\hline \multicolumn{2}{|c|}{ Protease } & NS & NS & NS & NS & NS & NS & NS \\
\hline \multicolumn{2}{|c|}{ RSBM $\times$ protease } & NS & NS & NS & NS & NS & NS & NS \\
\hline
\end{tabular}

${ }^{a, b, c}$ Means bearing uncommon superscripts within a column are significantly different;

${ }^{1} \mathrm{RSBM}=$ raw soybean meal; S. intestine = small intestine (duodenum + jejunum and ileum with the contents); SEM = pooled standard error of means; NS = non-significant; $\mathrm{G}+\mathrm{P}=$ gizzard + proventriculus.(SBM was replaced by RSBM at 0 , 10 and $20 \%$, equivalent to 0,30 and $60 \mathrm{~g} / \mathrm{kg}$, respectively and supplemented with proteas at $0.1,0.2$ of $0.3 \mathrm{~g} / \mathrm{kg}$, equivalent to $\sim 7500,15000$ and $\sim 22500$ PROT/kg of diet, respectively.)

\section{Discussion}

The values of TI, UA and NSI increased in line with increase in levels of RSBM in the diets. These results probably represent the first such data on raw soybeans of Australian origin. Results of this study are also evident on impacts of increasing levels of RSBM supplementation on the concentration of selected ANF in diets of non-ruminant animals. This information may help to know which level of ANF concentration could adversely affect the animals and thereby could help to intervene that reducing the negative impacts of ANF. The results agree with those of Frikha et al. (2012) who reported that protein solubility, TI, and UA correlate with the amounts of unheated soybeans in the diet. During the early periods $(1-10 \mathrm{~d}$ and $1-24 \mathrm{~d}$ ), increasing the level of RSBM in the diets had no influence on the FI, but the FI was decreased when considered over the entire trial period $(1-35 \mathrm{~d})$. This result partially agrees with the result of other researchers (Mogridge et al., 1996; ASA, 2004), who reported that birds fed on diets with RSBM experienced low FI. The reason for the reduction in feed consumption in the current study might be due to the negative impact of the ANF, particularly the TI in the RSBM. Feed passage rate, although not assessed in this study could be slowed down by poor pancreatic function in the presence of the Tl. Overall, this result gives evidence that when the age of birds advances, the adverse impact of ANF on FI was reduced, which shows that birds may be adopting ANF in diets in the later stages of their growth. The reduction in feed intake directly affected the BWG and feed efficiency, especially in the starter phase (1 - $10 \mathrm{~d}$ ). Previous researchers (ASA, 2004; Palacios et al., 2004; Romero and Plumstead, 2013) have shown that the performance of nonruminant animals is affected by concentration of dietary TI. Although microbial enzymes, including protease 
were included right from hatch, they were not able to completely eliminate the negative effects of $\mathrm{TI}$ and other ANF that are present in RSBM during the starter phase.

The birds tended to adjust to the factors with age, possibly as digestive function improved or in response to the supplemental enzymes. Body weight gain of birds was therefore not affected when assessed over 1 - $24 \mathrm{~d}$ or 1 - $35 \mathrm{~d}$. It has been reported (Rao et al., 2013) that broilers adapt to some ANF in the diet, especially with advance in age. It is anticipated that supplemental microbial protease could complement the activities of endogenous proteases. This assumption is based on the fact that increasing the level of the microbial protease in the diets improved the BWG of the birds in the periods of $1-10$ and $1-24 \mathrm{~d}$, and also tended to improve in the period $1-35 \mathrm{~d}$. The mechanism on how the microbial protease could reduce the adverse impact of ANF on birds might be through many ways, for example by breaking the larger molecules into smaller ones, which could be at harmless position for birds.

There are reports in literature (Yadav \& Sah, 2005; Barletta, 2011, Erdaw et al., 2015a) which indicate that microbial proteases are able to break down both stored proteins and proteinaceous anti-nutrients in diets. During the period from 1 to $24 \mathrm{~d}$ of this study, feed efficiency was improved in response to supplementation with microbial protease, but this response was weaker during the $1-10 \mathrm{~d}$ or $1-35 \mathrm{~d}$.

Protease supplementation has been shown to improve poultry performance (Cowieson \& Adeola, 2005; Rada et al., 2014), although most previous tests were conducted on diets containing only commercial SBM. As reported by scholars (Ravindran, 2013; Amerah, 2015), the mechanisms how the BWG and feed efficiency of birds were improved in the current study when supplementing their diets with microbial protease might also be due to the multi-faceted contribution of this enzyme, including complementarity effects with endogenous enzymes, contribution to reducing the gut viscosity, and by increasing the effectiveness of host (endogenous) enzymes and helping to alter the feed passage rate of the animals

There was no relative meat part of the birds that was affected by partially replacing the commercial SBM with the tested level of RSBM. Most of the measures, including the dressing percentage, breast, thighs and necks, were not affected by inclusion of protease, but the relative weight of drumsticks was increased. These results are in line with the body weight of birds assessed at $d 1-35$, which was not influenced due to supplementing RSBM in diets. This result partially disagrees with Rada et al. (2014), who reported that the meat parts of broilers were positively affected by the addition of microbial enzymes but the differences may be due to the nature of basal diets.

The small intestine and pancreas were significantly heavier in response to inclusion of RSBM in the diet. This result partially agrees with other researchers (Mogridge et al., 1996; Mayorga et al., 2011; Erdaw et al., 2015b) who reported that birds fed diets containing RSBM had heavier pancreas and duodenum. Organs associated with digestion and/or absorption may strive to maintain their functions through increase in size although this may be achieved by different mechanisms. As it was confirmed by the same authors (Erdaw et al., 2016c), the pancreas was the first vital organ that was being adversely affected by TI in RSBM. The duodenum was also found curling the pancreas, which most likely exposed that the two organs shared some physiological uncertainty. Therefore, duodenum could be the next adversely affected part of the small intestine, in this current study.

Regardless of the level of RSBM in the diets, increasing the inclusion rate of protease significantly reduced the weight of the small intestine during the starter phase. Ao (2011) reported that enzyme supplementation can reduce the negative impact of anti-nutrients. The duodenum was particularly affected in this study because it is the first part of the small intestine and holds the pancreas in place. It is likely that any change in the size of the pancreas would extend to this region of the small intestine. Other visceral organs were largely unaffected possibly because they are not directly involved with digestion or physical contact with the diet. This current result might show an effective strategy to reduce the adverse impacts of ANF, particularly $\mathrm{TI}$ on digestive organs of chicks at early age.

When increasing the level of the microbial protease in diets, the BWG was improved and weight of small intestine reduced, but no influence on weight of pancreas at $10 \mathrm{~d}$ of age. The results of this study showed that due to the supplementation of microbial enzymes in diets, the vital organs (e.g. pancreas and small intestine) might help to improve the physiological functions (secreting the functional enzymes and changing the intestinal structures) of birds, which generally enables an increase of the nutrient absorption (small intestines) and thereby leads to improved performance of birds, particularly at early age. These all might be mainly influenced by the supplements of microbial protease

\section{Conclusion}

Although some of the dietary treatment groups contained the TI concentration beyond the threshold level for non-ruminant animals, supplementation with microbial protease slightly enabled the birds to tolerate up to $20 \%$ of the RSBM, replacing the commercial SBM without greatly compromising bird productivity. The RSBM reduced growth during the early period (1 - 10 d), but over time, all treatment groups achieved almost 
the same BWG. A cost-benefit analysis may be needed, to ascertain the economic benefits, if any, of the inclusion of some RSBM in the diet for broiler chickens.

\section{Acknowledgements}

The financial support by DSM, Singapore and University of New England, Australia are gratefully acknowledged. The opinions expressed by the author are his own and do not, in any way, reflect on the sponsor.

\section{Authors' Contributions}

MME and PAI were in charge of the experimental design, implementation and writing the manuscript. All authors participated in interpreting and reviewing the results of the study.

\section{Conflict of Interest Declaration}

There are no conflicts of interest.

\section{References}

Amerah, A. M. 2015. Interactions between wheat characteristics and feed enzyme supplementation in broiler diets. Anim. Feed Sci. Technol. 199: 1-9.

Ao, T., 2011. Using exogenous enzymes to increase the nutritional value of soybean meal in poultry diet. In: El-Shemy, H. (Ed) Soybean and nutrition. In: Tech, Rijeka, Croatia, pp. 201-214.

AOAC, 2006a. Trypsin inhibitor activity -soybean, Int'l. Official Method 22-40.

AOAC, 2006b. Combustion analysis (LECO), Int'l Official Method 990.03.

AOAC, 2006c. Acid hydrolysis, Int'I Official Method 982.30 E (a), Chp. 45.3.05.

AOCS, 2006a. Urease activity, Soybeans- Chemistry and technology, Int'l Official Method Ba 9-58.

AOCS, 2006b. Combustion analysis (LECO), Int'l Official Method, Ba 11-65.

Araba, M. \& Dale, N.,1990. Evaluation of protein solubility as an indicator of over-processing soybean meal. Poult. Sci. 69: 76-83.

ASA (American Soyabean Association), 2004. Whole soybeans in diets for poultry. Acessed in February 2016: http://www.thepoultrysite.com/articles/194/whole-soybeans-in-diets-for-poultry.

Barletta, A., 2011. Introduction: current market and expected developments. In: Bedford, M.R. \& PartridgE, G.G. (Eds) Enzymes in Farm Animal Nutrition, CABI, Wallingford, UK, pp. 1-11.

Căpriţă, R., Căpriţă, A. \& Creţescu, I., 2010. Protein solubility as quality index for processed soybean. Scientific Papers Anim. Sci. Biotechnol. 43: 375-378.

Chen, Y., Duan, W., Wang, L., Zhang, S. \& Zhou,Y., 2013. Efects of thermostable phytase supplementation on the growth performance and nutrient digestibility of broilers. Int'l J. Poult. Sci. 12: 441-444.

Costa, F. G. P., Goulart, C. C., Figueiredo, D. F., Oliveira, C. F. S. \& Silva, J. H. V., 2008. Economic and environmental impact of using exogenous enzymes on poultry feeding. Int'l J. Poult. Sci. 7: 311-314.

Cowieson, A. \& Adeola, O., 2005. Carbohydrases, protease, and phytase have an additive beneficial effect in nutritionally marginal diets for broiler chicks. Poult. Sci. 84:1860-1867.

Dosković, V., Bogosavljević-Bosković, S., Pavlovski, Z., Milošević, B., Škrbić, Z., Rakonjac, S. \& Petričević, V., 2013. Enzymes in broiler diets with special reference to protease. World's Poult. Sci. J. 69: 343-360.

Dourado, L.R.B., Pascoal, L.A.F., Sakomura, N.K., Costa, F.G.P. \& Biagiot,T.I. D., 2011. Soybeans (Glycine max) and soybean products in poultry and swine nutrition, In: Dora Krezhova (Ed) Recent Trends for Enhancing the Diversity and Quality of Soybean Products. InTech, Rijeka, Croatia, pp. 175-190.

EFSA (European Food Safety Authority), 2009. Safety and efficacy of Ronozyme® ProAct (serine protease) for use as feed additive for chickens for fattening ${ }^{1,2}$. J. EFSA: 1185, 1-15.

EFSA (European Food Safety Authority). 2016. Scientific opinion on safety and efficacy of Ronozyme HiPhos GT (6phytase) as feed additive for poultry and pigs, pp, 10.

Erdaw, M. M., Perez-Maldonado, R. A., Bhuiyan, M. \& lji, P. A., 2015b. Response of broiler chicks fed on steam- or coldpelleted diets containing raw full-fat soybean meal. In Proc. $20^{\text {th }}$ European Symp. Poult. Nutr. 24-27 Aug 2015, in Prague, Czech Republic, pp. 179-180.

Erdaw, M. M., Bhuiyan, M. \& lji, P.A., 2016a. Enhancing the nutritional value of soybeans for poultry through supplementation with new-generation feed enzymes. Word's Poult. Sci. J. 72: 307-322.

Erdaw, M. M., Perez-Maldonado, A. R., Bhuiyan, M. and lji, P.A., 2016c. Effects of diet containing raw, full-fat soybean meal and supplemented with high-impact protease on relative weight of pancreas for broilers. In the Proceedings of $31^{\text {st }}$ Biennial (Australian \& New-Zealand Societies) Conf. Anim. Prod., 4-7 July 2016, Glenelg, Adelaide, Australia.

Erdaw, M. M., Perez-Maldonado, R. A., Bhuiyan, M. \& lji, P. A., 2015a. Replacement value of raw full-fat soybean for commercial soybean meal supplemented with a new-generation protease. In the proc $20^{\text {th }}$ European Symp. Poult. Nutr. 24-27 Aug 2015, in Prague, Czech Republic, pp. 418-419.

Erdaw, M. M., Perez-Maldonado, R.A., Bhuiyan, M. \& lji, P.A., 2016b. Physicochemical properties and enzymatic in vitro nutrient digestibility of full-fat soybean meal. J. Food. Agric. Environ.14: 85-91.

Friedman, M. \& Brandon, D. L., 2001. Nutritional and health benefits of soy proteins. J. Agric. Food. Chem. 49: 10691086. 
Frikha, M., Serrano, M. P., Valencia, D. G., Rebollar, P. G., Fickler, J. \& Mateos, G. G., 2012. Correlation between ileal digestibility of amino acids and chemical composition of soybean meals in broilers at 21 days of age. Anim. Feed Sci. Technol. 178: 103-114.

Guggenbuhl, P., Waché, Y. \& Wilson, J. W., 2012. Effects of dietary supplementation with a protease on the apparent ileal digestibility of the weaned piglet. J. Anim. Sci. 90:152-154.

Liu, K.S. (ed) (1997). Soybeans. chemistry, technology, and utilization. Chapman and Hall, New York, pp, 532

Mayorga, M. E., Vieira, S. L. \& Sorbara, J. O. B., 2011. Effects of a mono-component protease in broiler diets with increasing levels of trypsin inhibitors. XXII Latin American poultry Congress. Retrieved on 25 Oct 2016. Available online: http://en.engormix.com/MA-poultry-industry/nutrition/articles/effects-mono-component-protease-t1902/141p0.htm

Minitab 17 Statistical Software. 2013. [Computer software]. State College, PA: Minitab, Inc. (www.minitab.com).

Mogridge, J., Smith, T.\& Sousadias, M., 1996. Effect of feeding raw soybeans on polyamine metabolism in chicks and the therapeutic effect of exogenous putrescine. J. Anim. Sci. 74: 1897-1904.

Newkirk, R., 2010. Soybean. Feed industry guide,1st edition. Canadian Int'l Grains Institute, p. 48.

Palacios, M., Easter, R., Soltwedel, K., Parsons, C., Douglas, M., Hymowitz, T. \& Pettigrew, J., 2004. Effect of soybean variety and processing on growth performance of young chicks and pigs. J. Anim. Sci. 82:1108-1114.

Pettersson, D. \& Pontoppidan, K., 2013. Soybean meal and the potential for upgrading its feeding value by enzyme supplementation. In: El-SHEMY, A. (Ed) Soybean - Bio-Active Compounds, pp. 288-307. Intech, Open Access Publisher

Popescu, A. \& Criste, R., 2003. Using full fat soybean in broiler diets and its effect on the production and economic efficiency of fattening. J. C. European. Agri. 4:167-174.

Rada, V., Lichovnikova, M. \& Foltyn, M., 2014. The effect of serine protease on broiler growth and carcass quality. Acta Fytotechnica et Zootechnica. 17: 87-89.

Rao, S. B. N., Prasad, K. S. \& Rajendran, D., 2013. Recent advances in amelioration of anti-nutritional factors in livestock feedstuffs. In: Sampath, K.T., Jyotirmoy, G. and Raghavendra, B. (Eds) Animal Nutrition \& Reproductive Physiology (Recent Concepts), Publisher: Satish Serial Publishing House, Delhi, India, Editors: pp. 655-678.

Ravindran, V. 2013. Feed enzymes: The science, practice, and metabolic realities. J. Appl. Poult. Res. 22: 628-636.

Romero, L. \& Plumstead, P., 2013. Bio-efficacy of feed proteases in poultry and their interaction with other feed enzymes. In the proc. $24^{\text {th }}$ Annu. Australian Poult. Sci. Symp. Sydney, New South Wales $17^{\text {th }}-20^{\text {th }}$ Febr. 2013.

Shi, S. R., Lu, J., Tong, H. B., Zou, J. M. \& Wang, K. H., 2012. Effects of graded replacement of soybean meal by sunflower seed meal in laying hen diets on hen performance, egg quality, egg fatty acid composition, and cholesterol content. J. Appl. Poult. Res. 21: 367-374.

Yadav, J. \& Sah, R., 2005. Supplementation of corn-soybean based broiler's diets with different levels of acid protease. J. Institute of Agric. Anim. Sci. 26:65-70. 